\title{
Factors of Agricultural Cooperation Development
}

\author{
Vladimir Egorov ${ }^{1}$, Andrey Inshakov ${ }^{2 *}$ \\ ${ }^{1}$ Doctor of economics, doctor of history, professor of Plekhanov Russian University of Economics, Moscow, Russia \\ ${ }^{2}$ Junior Researcher, Plekhanov Russian University of Economics, Moscow, Russia \\ *Email: aero789@mail.ru
}

\begin{abstract}
The article is devoted to the conceptual aspects of the development of agricultural cooperation. The authors have analysed subjective and objective prerequisites for the growth of cooperative associations of small rural producers. The article argues that objective factors determining the genesis of agricultural cooperation, namely, the presence of ownership of small rural producers, which allows them to maintain the status of independent owners, but not sufficient from the point of view of efficiency in a market economy, and integration into the market remain relevant in modern cooperative practice. The problems of domestic cooperative legislation are revealed. The statistical data presented in the article allowed us to show that the reason for the current stagnation of the Russian agricultural cooperative sector is rooted precisely in the low marketability of small farms. Based on correlation analysis, the main subjects of cooperation of the agricultural complex of Russia - industrialised farms are shown.
\end{abstract}

Keywords: The genesis of agricultural cooperation, Industrial cooperation, Public organisation, The proletarianisation of the rural population, Private property, commodity farms, Commercial thinking, Cooperative legislation.

\section{INTRODUCTION}

Industrial cooperation in general and agricultural cooperation, in particular, constitute a unique socioeconomic structure based on special relationships that produce specific essential features and characteristics.

Although, by their nature, cooperatives function on the socialised property and have external signs of social consolidation, an attempt to define them as public organisations seem to be a dead-end.

Indeed, one type of cooperative association, namely consumer unions, fully corresponds to a public organisation's characteristics that do not differ in essence from any other community of individuals seeking to jointly obtain intellectual or material benefits. In this sense, the consumer society is no different from the book-lovers community, lovers of classical music or horse riding.

Consumer cooperation, in contrast to production, is a natural form of concentration of small property and, in this case, a completely equal form of the capitalist organisation of the economy was born as a reaction of the proletarian part of the population to the material differentiation of society in the course of forced capitalisation.

Russia, in which the capitalisation of the public economy took place by paternalistic methods and, therefore at a forced pace, has become a country with an extensive scale of development of consumer unions. The scale of the spread of Russian consumer cooperation initiates, in general, an incorrect conclusion about some particular complementarity of the Russian society to cooperation.

In fact, the cooperative form of economic organisation was and is at the initial stage of development since, unlike consumer cooperation, it requires certain objective prerequisites that have not finally matured in modern Russia. Suppose no other conditions are necessary for creating consumer societies other than the desire of consumers to cooperate in obtaining goods and services. In that case, structural prerequisites are required for forming a cooperative sector of the economy. 


\section{MATERIALS AND METHODS}

Theoretical analysis (logical method) of the works of domestic and foreign authors to identify the essential features of cooperation. Comparison of consumer and production cooperatives to identify their fundamental differences. Domestic cooperative legislation's theoretical analysis (logical method) to determine its problems. The correlation analysis method made it possible to identify the subjects of cooperation of the agricultural complex of Russia. The statistical method is applied to identify the causes of the current stagnation of the Russian agricultural cooperative sector.

\section{THEORETICAL FOUNDATIONS OF COOPERATION}

Bearing in mind the emergence of cooperation in the agricultural sector of the public economy, A.V. Chayanov wrote: "The emergence and development of agricultural cooperation were essentially organic and spontaneous, similar to the development of capitalism and other national economic systems"[1].

Ignoring the essential differences between consumer and production cooperation leads to several methodological and practical errors. Firstly, identifying these types of cooperative associations determines the theoretical and practical understanding of the entire cooperative as an exclusively public organisation, not focused on profit. Hence the frequent demands of cooperators about the need to exempt their enterprises from taxes, or, on the contrary, the desire of officials to extend tax approaches to all cooperative associations, assuming their commercial content.

Drawing a clear distinction between the "public" organisation of consumers and the cooperative organisation of the economy, the classics of the theory of cooperation advocated a differentiated approach to assessing their social prospects. For example, C. Gide wrote about the differences in production cooperation: "That's why we believe in the future of cooperation. Because we see in it a manifestation of natural law, more powerful than humanity, a law that acts spontaneously, regardless of human fluctuations and weaknesses" [2].

In contrast to the genesis of consumer unions, the emergence of cooperation of the production C. Gide considered the process objective and not the will of the oppressed masses or the activities of progressive personalities. The prominent theorist of cooperation, M.N. Tugan-Baranovsky, wrote on the same issue: "a cooperative is an economic enterprise, like any other. The cooperative addresses, first of all, the economic interest of a person." And further: "A cooperative enterprise is not a charitable institution, not a propaganda society, not a political organisation and not a workers' union. It is an economic organisation in the interests of a certain group of persons..." [3].

Secondly, the non-differentiated vision of cooperation initiates continuous attempts to use cooperation as a mechanism to prevent the proletarianisation of the population. By the way, it should be noted that the exceptional popularity of the ideas of socialism in the second half of the 19th century, including in Russia, gave rise to a social movement that did a lot both to popularise cooperative ideas and to plant cooperation among the rural poor. Believing that the development of agricultural cooperation, among other things, requires no other prerequisites than "accustoming peasants to diligent collective work," enthusiastic cooperators sought to plant cooperation by all available methods: through material encouragement of association in partnerships, the creation of special funds, the dissemination of best practices in sizeable collective farming. Most of the cooperatives created by such methods immediately ceased to exist as soon as the "trickle of material replenishment dried up."

By the way, it should be noted that today's Russian projects of planned "planting of agricultural cooperation", in addition to surprise, cannot cause other feelings [4].

Thirdly, the lack of a clear understanding of the nature and functional space of various types of cooperative associations generates annoying legal incidents of combining fundamentally different cooperative and other economic entities in legislation. For the first time in the world cooperative practice in 1995, the Federal Law of the Russian Federation was adopted, introducing the term "agricultural consumer cooperation" [5].

The connection in the federal law of organisations: social and economic was justified by the vague explanation that "the purpose of agricultural consumer cooperation is, first of all (not to increase the efficiency of commodity production - auth.) in strengthening the consolidation of commodity producers in the market and only secondly - in the development of specialisation, in the establishment of processing, etc., which is often put in the first place, as well as the tasks of agricultural production cooperation" [6].

The intellectuals and legislators who made the incident were guided by the understandable logic of using the Centre-union apparatus inherited from Soviet times to facilitate the market adaptation of the Russian village, due to objective reasons, not ready for broad industrial cooperation. In practice, this collision gave rise to the destruction of another level. According to the Civil Code of the Russian Federation, consumer cooperatives were defined as non-profit, and production cooperatives as commercial organisations. 
The same conceptual confusion explains another legislative "absurdity", namely, the possibility of combining both individuals and legal entities in agricultural cooperative enterprises, defined by the law "On Agricultural Cooperation".

Of course, the combination of the unconnected emasculated the natural advantage of the cooperative form of economic organisation, which consists in creating, through the harmonisation of labour and property, the institutional potential of highly motivated work. According to the logic of the legislators, small commodity producers who need to socialise farms due to the lack of individual means to increase their efficiency and enterprises based on hired labour (generally having limited use in agriculture) could unite in a cooperative.

In contrast to the consumer, industrial cooperation, being a natural direction of concentration of small rural producers, in addition to subjective prerequisites: the desire of individuals for interaction and complementary state policy, can be formed only in the presence of objective conditions. In this regard, attempts to impose or accelerate production cooperation by political or administrative methods are counterproductive. Moreover, the lack of understanding of this leads to unreasonable financial costs for promoting cooperative ideas, the artificial formation of agricultural cooperatives on social and economic "soil", unsuitable for cooperation.

The primary condition for the genesis of agricultural production cooperation is the presence of private property; the desire to multiply it and use it effectively to obtain the most significant commercial benefit encourages its owners to combine sales, supply, lending or the technological cycle as a whole.

The world experience of initiating proletarian cooperatives has shown the failure of hopes to implement stable collective enterprises. Precisely because all the attempts of the pioneers of cooperation failed, they tried through cooperation to help, first of all, the proletarianisation mass of the population.

A distinctive feature of associations of representatives of low-income groups of the population from genuine cooperatives is the absence of cooperative property formed by socialisation [7]. The lack of property among the proletarians united in cooperation inevitably actualises the problem of finding means for its existence (replaced by resources received from benefactors, the state, etc.) [8] and, thus, emasculates the amateur character, which in fact is the fundamental feature of this economic form.

Violation of the fundamental principle of selfactivity of cooperation always leads to the need for state participation in the functioning of associations. Thus, the state played a decisive role in creating proletarian cooperatives in France and Germany [9]. And now attempts to initiate cooperation in the absence of objective grounds (in this case, small property) always rest on the primary condition - state funding [10].

What is not unimportant, not only the absence of small property, in itself becomes an insurmountable obstacle to the cooperation of the proletarian strata of the population, but also the lost mentality inherent in the owners-producers, commitment to egalitarianism, the desire to break out into the "capitalists", but not to become an equal member of the "free association". Small private property that is not socialised, but the acquired property (from the help of the state, patrons, etc.) is perceived by the poor, united in cooperatives, not as a means of increasing the efficiency of commodity economy, which needs to be multiplied, but as an object of exploitation, which makes it possible to receive wages. An apt definition of proletarian unions is contained in work published in St. Petersburg in 1906 under the pseudonym "Friends of Freedom and Order".

"The main reason for all the failures, attempts in this regard (the development of industrial workers' cooperatives - auth.), lies not at all in the lack of money, as many defenders of the associations claimed. During the fever that seized French society at the end of the 40s, the state and philanthropists more than once donated vast sums of money to the organisation of productive associations; in England, according to an adherent of the Goliok association, the amount of money spent on attempts at cooperative farming should be considered many millions, but all these enormous costs did not save the association's cause and died without a trace; this reason lies in the difficulty of creating and organising the necessary labour forces and providing them with specific properties of mind and character and a certain discipline [11].

The lack of independent commercial thinking, economic decision-making skills, and skills that acquire a specific value in a market economy doom cooperatives of low-income groups of the population to failure. In addition, proletarian associations, deprived of naturally socialised cooperative property, lose the system-forming principle that determines the obligation of high moral principles as the natural basis of the cooperative form of economic organisation [10].

\section{THE MARKET NATURE OF COOPERATION}

Mentioned above is confirmed by the data of a study of peasant farms carried out in the Belgorod, Lipetsk, Nizhny Novgorod regions, Krasnodar and Stavropol Territories in June-July 2018 (Figure 1). 


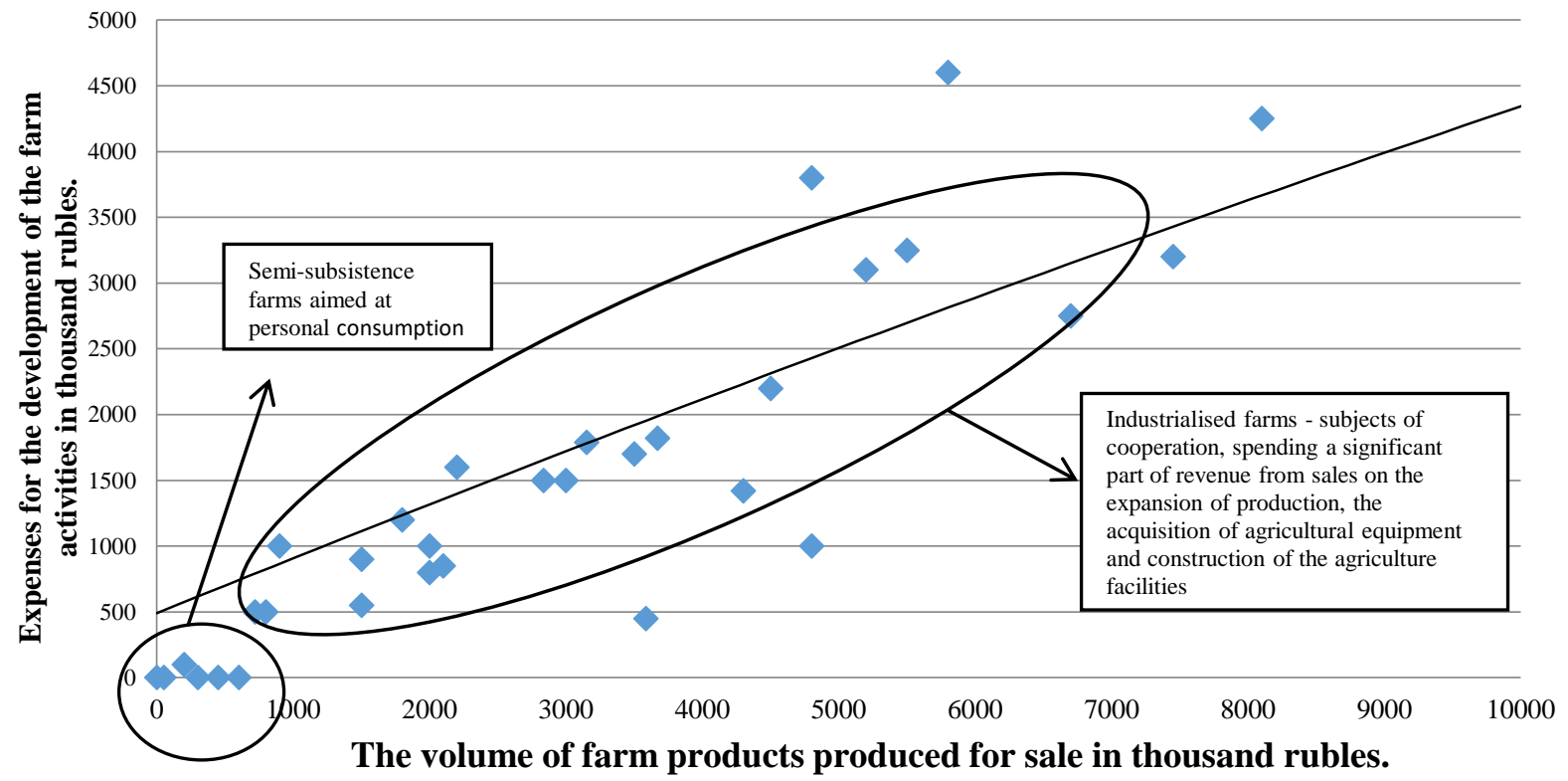

Figure 1 A study of peasant farms carried out in the Belgorod, Lipetsk, Nizhny Novgorod regions, Krasnodar and Stavropol Territories in June-July 2018.

The indicators shown in the diagram show that the greatest desire of farmers to cooperate is manifested in the environment of relatively wealthy owners who receive an annual income of over 1 million rubles.

Another objective basis, closely related to the first, is the commodity nature of agriculture. Only the market and commercial benefits, but not personal consumption, determine the craving of small owners to cooperate.

In general, cooperation cannot exist outside the market economy. The presence of the cooperative sector of the economy within the framework of the Soviet planning and administrative system led to its deep essential mutation. The shifts that occurred, for example, in the collective farm system were so significant that the differences in its content from the state farm had a conditional, only formally perceptible meaning.

Only commodity-money relations and the focus of small owners on obtaining commercial benefits stimulate the search by small producers for opportunities (including in pooling resources) to increase the efficiency of their economy.

The reason for the current stagnation of the Russian agricultural cooperative sector is rooted precisely in the low marketability of small farms. The answer to the question about the reasons for failures in the cooperation of Russian agriculture is contained in the "Concept of development of agricultural consumer cooperatives" itself. According to the data provided in the concept, from 1990 to 2004, the share of the products of peasant farms and private subsidiary farms in the total gross production of the industry increased from $26.3 \%$ to $56.9 \%$, which indicates not an increase in the efficiency of farms, but the degradation of agriculture, since of $57.4 \%$ of the crop production of the "individual-family sector", only $8.4 \%$ was produced by small producers, and the rest in private subsidiary farms, of $56.7 \%$ of livestock products, only $2.6 \%$, of $93.8 \%$ grown in individually - in the family sector of potato production, peasant farms accounted for only $2.0 \%$ of the total volume, from $85.1 \%$ of vegetables $4.9 \%$, from $54.9 \%$ of livestock and poultry $-2.4 \%$, from $55 \%$ of milk $-2.8 \%$, from $68.2 \%$ of wool $-10.9 \%$ [12].

As an illustration of the low marketability of small rural farms in Russia as one of the obstacles to the cooperative self-sufficiency of the village, we present data on farms in Finland. All farms in this country export more than 40 thousand tons of pork (with 200 thousand tons of annual national production). On a limited area of 470 hectares, farms produce 150 million euros worth of vegetables and flowers for sale per year [13].

Thus, the modern agricultural sector of the Russian economy, which is not adaptive to the market economy (excluding large corporations, which are emphasised in the current state policy of import substitution), does not generate conditions for the cooperation of villagers. A rare exception is regions with rapidly growing intensive agriculture. Thus, according to the regional agricultural 
administration, from 2002 to 2005, the total volume of agricultural production of the Belgorod region increased by $71 \%$ and reached 58.2 billion rubles. The share of private subsidiary farms of the population in the industry's total output over the same period decreased by $43.5 \%$ to $24.6 \%$, and the percentage of farms increased from $2.8 \%$ to $3.7 \%$. From 2005 to 2010 , the volume of commercial products of the farm increased in crop production from 935.5 million rubles to 1,552.6 million rubles, and in animal husbandry from 140.1 million rubles to 505.5 million rubles [12].

The data of the last agricultural census indicate a further increase in marketability by peasant farms of the Belgorod region. Of the total number of commodity farms in the Central Federal District, $8.6 \%$ farms in Belogorye. At the same time, 59.7\% sell over $90 \%$, $17.8 \%$ - from 75 to $90 \%, 12.9 \%$ - from 50 to $75 \%$, and $6.5 \%$ - from 25 to $50 \%$ of the annual grain harvest. Their total marketability is $80 \%$ [14].

As a consequence of the increase in marketability, the desire of Belgorod farmers to cooperate is growing, measurements of which have been carried out for almost two decades (the study is conducted at intervals of three years). Farmers are asked to answer the question, "Do you use joint (cooperative) marketing of products, supply and common use of machinery and equipment in your activities with other farmers?" (Table 1).

\section{CONCLUSION}

Thus, the genesis of the cooperative segment of the agricultural sector of the economy is a consequence of natural socio-economic processes that actualised the growth of collective associations of small commodity producers in the conditions of their transition from natural to the commodity-money economy. The factors that gave rise to agricultural cooperation in the distant past remain the necessary material basis for the growth of the cooperative sector today. As a few centuries ago, the starting points, the foundation of cooperation is the small ownership of farmers, sufficient to preserve their status as owners, and integration into market relations that stimulate the search for missing resources to increase the efficiency of individual enterprises.

The current state cooperative policy should be oriented toward forming these material prerequisites.

\section{REFERENCES}

[1] A.V. Chayanov, Selected works [Izbrannye proizvedeniya] // Moscow: Moscow worker [Moskovskij rabochij], 1989, 190 p.

[2] Charles Gide, About cooperation [O kooperacii]// Moscow: Universal Library [Universal'naya biblioteka], 1915, $21 \mathrm{p}$.

[3] M.I. Tugan-Baranovsky, Social foundations of cooperation [Social'nye osnovy kooperacii] // M., 1916, pp. 68-69.

[4] The concept of development of agricultural consumer cooperatives. Ministry of Agriculture of the Russian Federation on March 29, 2016 [Koncepciya razvitiya sel'skohozyajstvennyh potrebitel'skih kooperativov. Ministerstvo sel'skogo hozyajstva RF 29 marta 2016], [Electronic resource]. URL: https://fsspk.ru/wpcontent/uploads/2014/03/koncepciya_2006.pdf (Accessed: 16.07.2018)

[5] CL RF [SZ RF], 1995, № 50, Article 4870.

[6] E.S. Stroev, S.A. Nikolsky, V.I. Kiryushin, Multicultural agrarian Economy and the Russian village (the mid-80s-90s 20th century) [Mnogoukladnaya agrarnaya ekonomika i rossijskaya derevnya (seredina 80-h- 90-e gg. HKH stoletiya)] // E.S.Stroev, S.A. Nikolsky, V.I. Kiryushin et al.: Edited by E.S. Stroev, M.: Kolos, 2001, 398 p.

[7] K.A. Pazhitnov, Fundamentals of cooperatism [Osnovy kooperatizma] // M. 1917, pp. 67, 85, 86.

[8] G. David, Socialism and the cooperative movement [Socializm i kooperativnoe dvizhenie] // St. Petersburg, 1906, pp. 12-15.

[9] N. Lakes, Consumer Society, A historical sketch of their development in Western Europe, America and Russia [Obshchestva potrebitelej. Istoricheskij ocherk ih razvitiya $\mathrm{v}$ Zapadnoj Evrope, Amerike i Rossii], St. Petersburg, 1899, $122 \mathrm{p}$.

Table 1. The proportion of farmers who responded positively by year (in $\%$ of the total number of respondents) [14]

\begin{tabular}{|l|l|l|l|l|l|l|}
\hline 2002 & 2004 & 2007 & 2010 & 2013 & 2015 & 2018 \\
\hline $3 \%$ & $11 \%$ & $19 \%$ & $21 \%$ & $25 \%$ & $27 \%$ & $31 \%$ \\
\hline
\end{tabular}


[10] Report of the UN Secretary-General "On national experience in promoting the cooperative movement" [Doklad general'nogo sekretarya OON «O nacional'nom opyte v oblasti sodejstviya kooperativnomu dvizheniyu»] // BPI 41.27.2. (1989) 3-13.

[11] Productive partnerships as a tool for attempts to resolve the social issue [Proizvoditel'nye tovarishchestva, kak orudie dlya popytok razresheniya social'nogo voprosa] // St. Petersburg: Publishing house of "Friends of Freedom and Order" [SPb: Knigoizdatel'stvo «Druzej svobody i poryadka»], 1906, pp. 18-19.

[12] The concept of development of agricultural consumer cooperatives. Ministry of Agriculture of the Russian Federation. March 29, 2006 [Koncepciya razvitiya sel'skohozyajstvennyh potrebitel'skih kooperativov. Ministerstvo sel'skogo hozyajstva RF. 29 marta 2006], [Electronic resource]. URL: http://fsspk.ru/wpcontent/uploads/2014/03/koncepciya_2006.pdf (Accessed: 16.07.2018)

[13] V.G. Egorov, Cooperation in modern Russia [Kooperaciya v sovremennoj Rossii] // St. Petersburg: Aleteya, 2013, 407 p.

[14] Results of the All-Russian Agricultural Census of 2018 (in 8 volumes), Volume 2. The number of objects of the All-Russian Agricultural Census of 2016. Labour resources and their nature, [Itogi Vserossijskoj sel'skohozyajstvennoj perepisi 2018 goda (v 8 tomah), Tom 2, CHislo ob"ektov Vserossijskoj sel'skohozyajstvennoj perepisi 2016 goda. Trudovye resursy $\mathrm{i}$ ih harakter.] The official publication, Moscow: SIC "Statistics of Russia" [Oficial'noe izdanie M.: NIC «Statistika Rossii»], 2018, pp. 139-141. The authors performed the calculations. 